\title{
PETROLOGIC AND MINERALOGIC INVESTIGATION OF SOME CRYSTALLINE ROCKS RETURNED BY THE APOLLO 14 MISSION*
}

\author{
A.J.GANCARZ, A.L.ALBEE and A.A.CHODOS \\ The Lunatic Asylum of the Charles Arms Laboratory \\ Division of Geological and Planetary Sciences, \\ California Institute of Technology, \\ Pasadena, California 91109, USA \\ Received 4 August 1971 \\ Revised version received 11 August 1971
}

\begin{abstract}
Apollo 14 crystalline rocks ( 14053 and 14310$)$ and crystalline rock fragments $(14001,7,1 ; 14001,7,3 ; 14073$; $14167,8,1$ and $14321,191, \mathrm{X}+1$ ) on which $\mathrm{Rb} / \mathrm{Sr},{ }^{40} \mathrm{Ar}-{ }^{39} \mathrm{Ar}$, or cosmic ray exposure ages have been deiermined by our colleagues were studied with the electron microprobe and the petrographic microscope. Rock samples 14053 and 14310 are mineralogically and petrologically distinct from each other. On the basis of mineralogic and petrologic characteristics all of the fragments, except $14001,7,1$, are correlative with rock 14310. Sample 14073 is an orthopyroxene basalt with chemical and mineralogic affinities to 'KREEP', the 'magic' and 'cryptic'. components. Fragment $14001,7,1$ is very similar to Luny Rock $I$.
\end{abstract}

\section{Introduction}

As described by the Apollo 14 Preliminary Examination Team, fragmental rocks with complex textural relationships predominate in the Apollo 14 samples [1]. Out of the total $43 \mathrm{~kg}$ sample returned the only crystalline rocks which weigh over $50 \mathrm{~g}$ are 14053 $(251 \mathrm{~g})$ and $14310(3439 \mathrm{~g})$. However, smaller samples of crystalline rock were returned and are also available as fragments in the soil samples and as clasts within the breccia samples.

In this study we describe the petrology and mineralogy of seven crystalline samples, on which $\mathrm{Rb} / \mathrm{Sr},{ }^{40} \mathrm{Ar}-{ }^{39} \mathrm{Ar}$, or cosmic ray exposure ages have been determined $[2,3]$. These isotopic investigations indicate the existence of two rock groups characterized by different crystallization and cosmic ray exposure ages. Data on the various samples are summarized in table 1. The purpose of this study is to characterize the dated samples petrographically and

\footnotetext{
* Contribution no. 2048.
}

to identify any differences which might permit the correlation of other individual lithic fragments with the dated fragments.

\section{Analytical techniques}

The analyses were made with a Materials Analysis Corporation model 5-SA3 electron microprobe interfaced with a PDP-8/L computer. Peak and background counting for up to 15 elements, online data processing and examination of the data was done on each spot. Consequently, relocation of the spot was not required. Standard operating conditions were $15 \mathrm{kV}$ with beam current integration and pulse height selection. Immediately prior to each quantitative analysis programmed peak searches for $\mathrm{Si}, \mathrm{Al}$ and $\mathrm{Mg}$ were run on the spot to be analyzed. Silicates, oxides, and phosphates were analyzed for most elements relative to a set of simple silicates, oxides, and phosphates using the general technique of Bence and Albee [4] and the interelement correction factors of Albee and Ray [5]. 
Table 1

Summary of sample data from Apollo 14 Preliminary Science Report [1], Turner et al. [3], Papanastassiou and Wasserburg [2] .

\begin{tabular}{|c|c|c|c|c|c|c|c|c|}
\hline Sample & Subnumber & Nature & Location & Weight & $\begin{array}{l}{ }^{38} \mathrm{Ar}-{ }^{37} \mathrm{Ar} \\
\text { exposure age }\end{array}$ & ${ }^{40} \mathrm{Ar}^{3}{ }^{39} \mathrm{Ar}$ age & $\mathrm{Rb} / \mathrm{Sr}$ age & $\left.\left({ }^{87} \mathrm{Sr}\right)^{86} \mathrm{Sr}\right) \mathrm{I}$ \\
\hline 14310 & slide 6 & $\begin{array}{l}\text { basalt grab } \\
\text { sample }\end{array}$ & 'smooth region' & $3439 \mathrm{~g}$ & $300 \mathrm{my}$ & $3.89 \mathrm{AE}$ & $3.87 \mathrm{AE}$ & 0.70036 \\
\hline 14053 & slide 17 & $\begin{array}{l}\text { basalt grab } \\
\text { sample }\end{array}$ & Cone Crater rim & $251 \mathrm{~g}$ & $\leqslant 30$ & 3.93 & 3.96 & 0.69948 \\
\hline 14073 & slide 8 & $\begin{array}{l}\text { basalt pebble } \\
\text { from trench }\end{array}$ & 'smooth region' & $10 \mathrm{~g}$ & & & 3.88 & 0.70034 \\
\hline \multirow[t]{3}{*}{14001} & & $\begin{array}{l}\text { coarse fines, } \\
\text { contingency } \\
\text { sample }\end{array}$ & 'smooth region' & & & & & \\
\hline & $14001,7,1$ & vesicular clast & & $0.062 \mathrm{~g}$ & 590 & 3.87 & \multicolumn{2}{|c|}{4.30 (model age) } \\
\hline & $14001,7,3$ & basalt clast & & $0.088 \mathrm{~g}$ & 260 & 3.90 & 3.89 & 0.70036 \\
\hline \multirow[t]{2}{*}{14167} & & $\begin{array}{l}\text { coarse fines, } \\
\text { comprehensive } \\
\text { sample }\end{array}$ & 'smooth region' & & & & & \\
\hline & $14167,8,1$ & basalt & & $0.067 \mathrm{~g}$ & 29 & 3.94 & & \\
\hline \multirow[t]{3}{*}{14321} & $191, \mathrm{X}-1$ & $\begin{array}{l}\text { breccia } \\
\text { basalt clast }\end{array}$ & Cone crater rim & $0.16 \mathrm{~g}$ & & & 3.95 & 0.69942 \\
\hline & 144,1 & $\begin{array}{l}\text { composite of } \\
\text { light-colored } \\
\text { basalt clasts }\end{array}$ & & $0.072 \mathrm{~g}$ & $\leqslant 30$ & 3.92 & & \\
\hline & $144, F$ & $\begin{array}{l}\text { composite of } \\
\text { dark-colored } \\
\text { clasts }\end{array}$ & & & $\leqslant 40$ & 3.93 & & \\
\hline
\end{tabular}

However, pure metals were used as standards for analyzing $\mathrm{U}, \mathrm{Th}$ and $\mathrm{Pb}$ and alloys were used as standards for the metal phase. The accuracy of the anal$y$ ses is about 2 or $3 \%$ for oxides constituting more than $5 \mathrm{wt} \%$ of the sample.

Polished thin sections $(14310,6 ; 14053,17 ; 14073,8)$ were provided by the curator of the lunar samples. The other samples were studied in micro-thin sections prepared from portions of the fragments used for the isotopic investigations $[2,3]$. These sections had an area of less than $1 \mathrm{~mm}^{2}$. In addition, grain mounts were made of the 'quintessence' separates prepared for the $\mathrm{Rb} / \mathrm{Sr}$ measurements. Sample heterogeneity is a problem for all samples since it is possible that neither the large thin sections nor the micro-thin sections fully represent the entire sample used for isotopic work.

The sections were studied by both optical and electron microprobe techniques. All analyzed points were examined optically and use of the term glass for an analysis indicates that the analyzed point was isotopic and contained relatively few inclusions. However, identification of apatite and whitlockite is based on the composition $[6,7]$.

\section{Sample descriptions}

All seven studied samples are basalts, but they exhibit marked differences in texture, composition, mineralogy, and shock features. As pointed out by the Preliminary Examination Team [1], the two largest samples (14310 and 14053) are distinctly different. Of the five other samples studied four are similar in many respects to sample 14310 and may be correlative, whereas one differs from both 14310 and 14053. Sys- 
Table 2

Phases present in the analyzed samples.

\begin{tabular}{|c|c|c|c|c|c|c|c|}
\hline & $14001,7,1$ & $14001,7,3$ & $\begin{array}{l}\text { Sample } \\
14053,17\end{array}$ & 14073,8 & $14167,8,1$ & 14310,6 & $\begin{array}{l}14321,191 \\
X-1\end{array}$ \\
\hline Iron metal & $\mathrm{x}$ & $\mathrm{x}$ & $\mathrm{x}$ & $\mathbf{x}$ & $\mathrm{x}$ & $\mathrm{x}$ & $\mathrm{x}$ \\
\hline Troilite & $\mathrm{x}$ & $\mathrm{x}$ & $x$ & $\mathbf{x}$ & $\mathrm{x}$ & $\mathrm{x}$ & $\mathbf{x}$ \\
\hline Zircon & $?$ & - & - & - & - & $\mathbf{x}$ & - \\
\hline Baddeleyite & - & - & - & - & - & $\mathbf{x}$ & - \\
\hline Rutile & $?$ & - & $?$ & - & - & - & - \\
\hline llmenite & 2 & $\mathrm{x}$ & (3) & (2) & $\mathrm{x}$ & (3) & $\mathrm{x}$ \\
\hline Chromian ulvospinel & $?$ & - & $\mathrm{x}$ & NO & - & NO & - \\
\hline Apatite & NO & $\mathrm{x}$ & $\mathrm{x}$ & $\mathrm{x}$ & - & $\mathrm{x}$ & $\mathrm{x}$ \\
\hline Whitlockite & (3) & $\mathrm{x}$ & $\mathrm{x}$ & $\mathrm{x}$ & - & $x$ & NO \\
\hline Cristobalite & NO & NO & (2) & NO & NO & NO & NO \\
\hline Olivine & NO & NO & $\mathrm{x}$ & NO & $(30)$ & $\mathrm{x}$ & NO \\
\hline Clinopy roxene & & (20) & $(50)$ & (25) & $(30)$ & $(40)$ & (25) \\
\hline Augite & $\mathrm{x})$ & $\mathrm{x}$ & $\mathrm{x}$ & $\mathrm{x}$ & $\mathrm{x}$ & $\mathrm{x}$ & $\mathrm{x}$ \\
\hline Pigeonite & $x(45)$ & $\mathrm{x}$ & $\mathrm{x}$ & $\mathrm{x}$ & $\mathrm{x}$ & $\mathrm{x}$ & $?$ \\
\hline Orthopyroxene & $\mathrm{x}$ & NO & NO & $(20)$ & NO & NO & NO \\
\hline Plagioclase & $x$ & $(75)$ & (40) & (50) & (35) & $(50)$ & (70) \\
\hline K-Ba feldspar & $x>(55)$ & - & $?$ & - & - & - & - \\
\hline Glass & $? \int$ & $\mathrm{x}$ & $\mathrm{x}$ & $\mathrm{x}$ & $\mathrm{x}$ & $\mathrm{x}$ & $\mathrm{x}$ \\
\hline U-Th-rich phase & - & $x$ & NO & - & - & $\mathrm{x}$ & - \\
\hline Fe-Ti-Zr silicate & - & $\mathrm{x}$ & NO & $x$ & NO & $x$ & NO \\
\hline Vugs & $\mathrm{x}$ & - & $\mathrm{x}$ & - & - & $\mathrm{x}$ & - \\
\hline
\end{tabular}

( ) = estimated modal proportion.

$\mathrm{x}=$ present.

NO $=$ not observed.

- $\quad=$ not observed, but looked for systematically.

? $\quad=$ identification not positive.

tematic descriptions of the samples are presented as a basis for comparison of the samples in a later section.

\subsection{Sample 14053}

Sample 14053 was collected as a grab sample near the rim of Cone Crater and weighed $251 \mathrm{~g}$ [8]. It was studied in polished thin section 14053,17 , which has an area of about $50 \mathrm{~mm}^{2}$.

This section is of an ophitic basalt composed predominantly of plagioclase (40\%), clinopyroxene $(50 \%)$ with minor ilmenite (3\%), cristobalite $(2 \%)$, troilite, Fe-metal, mesostasis and other minor phases (table 2). Vugs partially filled with plagioclase, pyroxene and ilmenite are present [9]. No olivine cores were found in the pyroxene, although such cores have been reported in this sample [1].

As is shown in plate Ia the texture is a true ophitic texture with interlocking stubby laths of plagioclase ( $\sim 0.5 \mathrm{~mm}$ long) enclosed in pyroxene grains ranging in length to $2 \mathrm{~mm}$. Ilmenite and cristobalite grains occur both enclosed by pyroxene grains and as large interstitial grains.

Plagioclase occurs as stubby laths exhibiting polysynthetic twinning and marked zoning. Analyses of one grain indicated a compositional variation from $\mathrm{An}_{90} \mathrm{Ab} \mathrm{b}_{10}$ in the core to $\mathrm{An}_{77} \mathrm{Ab}_{21} \mathrm{Or}_{2}$ on the rim (table 3, \#3-\#4).

Clinopyroxene occurs as large crystals optically exhibiting pronounced compositional zoning, compositional and structural discontinuities, and mosaic structure. The mosaic structure is like that seen in pyroxene in the Apollo 11 rocks $[6,10]$ and is probably not a shock effect. The compositional variation in the pyroxene is extreme and will surely excite the pyrox- 
Table 3

Representative electron probe analy ses of plagioclase feldspar.

\begin{tabular}{|c|c|c|c|c|c|c|c|c|}
\hline \multirow[b]{2}{*}{ wt $\%$} & \multirow{2}{*}{$\begin{array}{l}14001,7,1 \\
\text { rep. } \\
\# 1\end{array}$} & \multirow{2}{*}{$\begin{array}{l}14001,7,3 \\
\text { av. } 7 \\
\# 2\end{array}$} & \multicolumn{2}{|c|}{14053,17} & 14073,8 & $14167,8,1$ & 14310,6 & 14321,191 \\
\hline & & & $\begin{array}{l}\text { core } \\
\# 3\end{array}$ & $\begin{array}{l}\text { rim } \\
\# 4\end{array}$ & $\begin{array}{l}\text { av. } 7 \\
\# 5\end{array}$ & $\begin{array}{l}\text { av. } 5 \\
\# 6\end{array}$ & $\begin{array}{l}\text { av. } 6 \\
\# 7\end{array}$ & $\begin{array}{l}\text { rep. } \\
\# 8\end{array}$ \\
\hline $\mathrm{Na}_{2} \mathrm{O}$ & 2.08 & 0.64 & 1.14 & 2.35 & 0.61 & 0.76 & 0.70 & 0.75 \\
\hline $\mathrm{MgO}$ & $<0.01$ & 0.14 & 0.24 & 0.08 & 0.13 & 0.14 & 0.10 & 0.24 \\
\hline $\mathrm{Al}_{2} \mathrm{O}_{3}$ & 32.14 & 34.97 & 35.13 & 31.74 & 34.92 & 34.17 & 35.53 & 33.97 \\
\hline $\mathrm{SiO}_{2}$ & 49.58 & 44.61 & 46.08 & 49.70 & 44.75 & 45.18 & 44.87 & 45.28 \\
\hline $\mathrm{K}_{2} \mathrm{O}$ & 0.44 & 0.06 & 0.04 & 0.39 & 0.08 & 0.22 & 0.10 & 0.03 \\
\hline $\mathrm{CaO}$ & 15.36 & 19.82 & 18.54 & 15.76 & 19.22 & 18.05 & 19.01 & 19.28 \\
\hline $\mathrm{FeO}$ & 0.06 & 0.19 & 0.32 & 0.83 & 0.19 & 0.44 & 0.36 & 0.18 \\
\hline $\mathrm{BaO}$ & $<0.01$ & 0.04 & $<0.01$ & 0.02 & 0.13 & $<0.06$ & 0.01 & $<0.01$ \\
\hline Total $\equiv$ & 99.66 & 100.47 & 101.49 & 100.87 & 100.03 & 99.02 & 100.68 & 99.73 \\
\hline
\end{tabular}

Formula proportions

\begin{tabular}{|c|c|c|c|c|c|c|c|c|}
\hline $\mathrm{Na}$ & 0.19 & 0.06 & 0.10 & 0.21 & 0.05 & 0.07 & 0.06 & 0.07 \\
\hline $\mathrm{Mg}$ & $<0.01$ & 0.01 & 0.02 & $<0.01$ & 0.01 & 0.01 & 0.01 & 0.02 \\
\hline $\mathrm{Al}$ & 1.74 & 1.90 & 1.88 & 1.70 & 1.90 & 1.88 & 1.92 & 1.85 \\
\hline $\mathrm{Si}$ & 2.28 & 2.05 & 2.09 & 2.26 & 2.07 & 2.11 & 2.06 & 2.10 \\
\hline K & 0.03 & $<0.01$ & $<0.01$ & 0.02 & $<0.01$ & 0.01 & 0.01 & $<0.01$ \\
\hline $\mathrm{Ca}$ & 0.76 & 0.98 & 0.90 & 0.77 & 0.95 & 0.90 & 0.93 & 0.96 \\
\hline $\mathrm{Fe}$ & $<0.01$ & 0.01 & 0.01 & 0.03 & 0.01 & 0.02 & 0.01 & 0.01 \\
\hline \multirow[t]{2}{*}{$\mathrm{Ba}$} & $<0.01$ & $<0.01$ & $<0.01$ & $<0.01$ & $<0.01$ & $<0.01$ & $<0.01$ & $<0.01$ \\
\hline & $5.00^{*}$ & $5.00 *$ & $5.00^{*}$ & $5.00^{*}$ & $5.00^{*}$ & $5.00^{*}$ & $5.00 *$ & $5.00^{*}$ \\
\hline
\end{tabular}

* Normalization factor for catatoms.

ene specialist to a highly energetic state. As shown on fig. 1 and table 4 (\#3-\#6) magnesium pigeonite cores $\left(\mathrm{Wo}_{10} \mathrm{Fs}_{35} \mathrm{En}_{55}\right)$ are enclosed by augite $\left(\mathrm{Wo}_{25} \mathrm{Fs}_{45} \mathrm{En}_{30}\right.$ ), which grades to ferroaugite $\left(\mathrm{Wo}_{25} \mathrm{Fs}_{65} \mathrm{En}_{10}\right)$ and then to ferrohedenbergite $\left(\mathrm{Wo}_{40} \mathrm{Fs}_{55} \mathrm{En}_{5}\right)$. The ferrohedenbergite is on the rim of the grain adjacent to a mesostasis containing olivine $\left(\mathrm{Fa}_{95} \mathrm{Fo}_{5}\right)$, cristobalite, troilite, Fe-metal, ilmenite, $\mathrm{SiO}_{2}$-rich glass, and possibly fibers of $\mathrm{K}_{2} \mathrm{O}-\mathrm{BaO}$-rich feldspar. Such marked Fe enrichment with progressive crystallization is more typical of the Apollo 11 pyroxenes than of the Apollo 12 pyroxenes.

Opaque minerals occur as large anhedral grains (up to $0.5 \mathrm{~mm}$ ) throughout the rock as well as in the mesostasis. Analysis \#20 in table 4 is of a typical anhedral grain of ilmenite. Ilmenite also occurs as smaller crystals enclosed within pyroxene, suggesting that entrapment occurred while growth continued.

Anhedral grains of chromian ulvöspinel contain exsolution lamellae of ilmenite to $2 \mu$ thick and plates of metallic iron parallel to the octahedral planes. The ulvöspinel and ilmenite lamellae are similar to the coexisting pairs observed in the Apollo 12 rocks [11] (table 4, \#21-\#22). The ilmenite lamellae are much higher in $\mathrm{Cr}$ and $\mathrm{Mg}$ than the anhedral ilmenite (table 4 , \#20-\#21). Ilmenite grains also contain rare lamellae $(<0.1 \mu)$ which electron beam scans indicate are rutile.

Fe-metal occurs as globules encased in troilite and as discrete grains. The Ni content of the Fe-metal ranges from 0.1 to $4 \mathrm{wt} \%$ (fig. 2).

The mesostasis in this sample is extremely complex. 

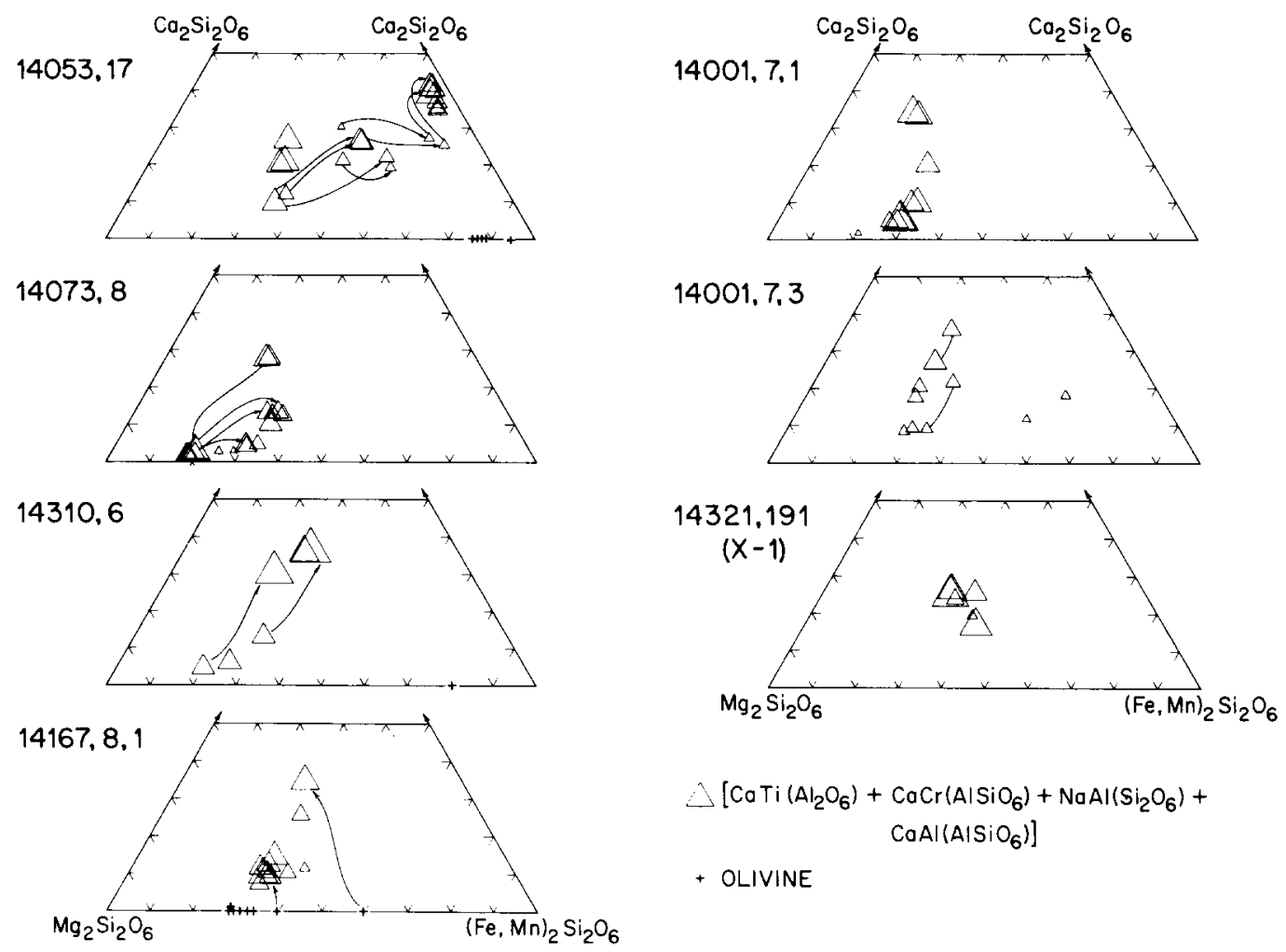

$$
\begin{aligned}
\triangle\left[\operatorname{CaTi}\left(\mathrm{Al}_{2} \mathrm{O}_{6}\right)+\right. & \operatorname{CaCr}\left(\mathrm{AlSiO}_{6}\right)+\operatorname{NaAl}\left(\mathrm{Si}_{2} \mathrm{O}_{6}\right)+ \\
& \left.\operatorname{CoAl}\left(\mathrm{AlSiO}_{6}\right)\right]
\end{aligned}
$$

+ OLIVINE

Fig. 1. Composition of pyroxenes from the studied samples. Solid lines indicate coexisting pairs of pyroxene and arrows indicate compositional variations from the core to the rim in a single grain. The size of the triangles is as indicated and discussed in the text (sect. 3.8). Note that only the pyroxenes from sample 14053,17 show extensive Fe enrichment.

It includes mosaic grains of cristobalite, phosphate minerals, $\mathrm{SiO}_{2}$-rich glass, fayalite, ilmenite, troilite, Fe-metal, and possibly tiny fibers of $\mathrm{K}_{2} \mathrm{O}-\mathrm{BaO}$ feldspar. Troilite and Fe-metal commonly occur in peculiar spongy masses, not abundant in other lunar rocks (fig. 3). These complex mesostasis areas are also shown in plate Ia. Within one area of mesostasis is a $150 \mu$ single crystal of olivine $\left(\mathrm{Fa}_{87} \mathrm{Fo}_{13}\right.$; table 4 , \#15) enclosing masses of the spongy troilite, Fe-metal and elongate globules $(<1 \mu)$ of $\mathrm{SiO}_{2}$-rich glass (fig. 4; table 5). Furthermore, a small vesicle $(<0.1 \mu)$ is associated with each of the $\mathrm{SiO}_{2}$-rich inclusions. These textural relationships strongly suggest late stage silicate melt immiscibility, as studied in detail by Roedder and Weiblen [12] . A colorless glass containing needles of phosphate minerals commonly occurs enclosed in ilmenite, but in sizes too small to analyze.

\subsection{Sample 14310}

Sample 14310 was a 3439 g grab sample collected from the 'smooth region' away from Cone Crater and was described by the Preliminary Examination Team [1]. It was studied in polished thin section 14310,6, which has an area of about $250 \mathrm{~mm}^{2}$. The section is of a subophitic, intergranular to intersertal, basalt composed predominantly of plagioclase (50\%) and clinopyroxene (40\%), with minor ilmenite, troilite, Fe-metal, mesostasis, and other minor phases (table 2). Vugs or mesostasis lost during preparation of the thin section comprise nearly $5 \%$ of the slide. Although the volumetric percentage of vugs is uncertain, they are present and are partially filled with euhedral plagioclase, pyroxene and ilmenite crystals [9].

The texture is quite distinct from most of the Apollo 11 and 12 samples and distinct from thin sec- 
Table 4

Representative electron probe analy ses of pyroxene, olivine, and Fe-Ti-Cr oxides.

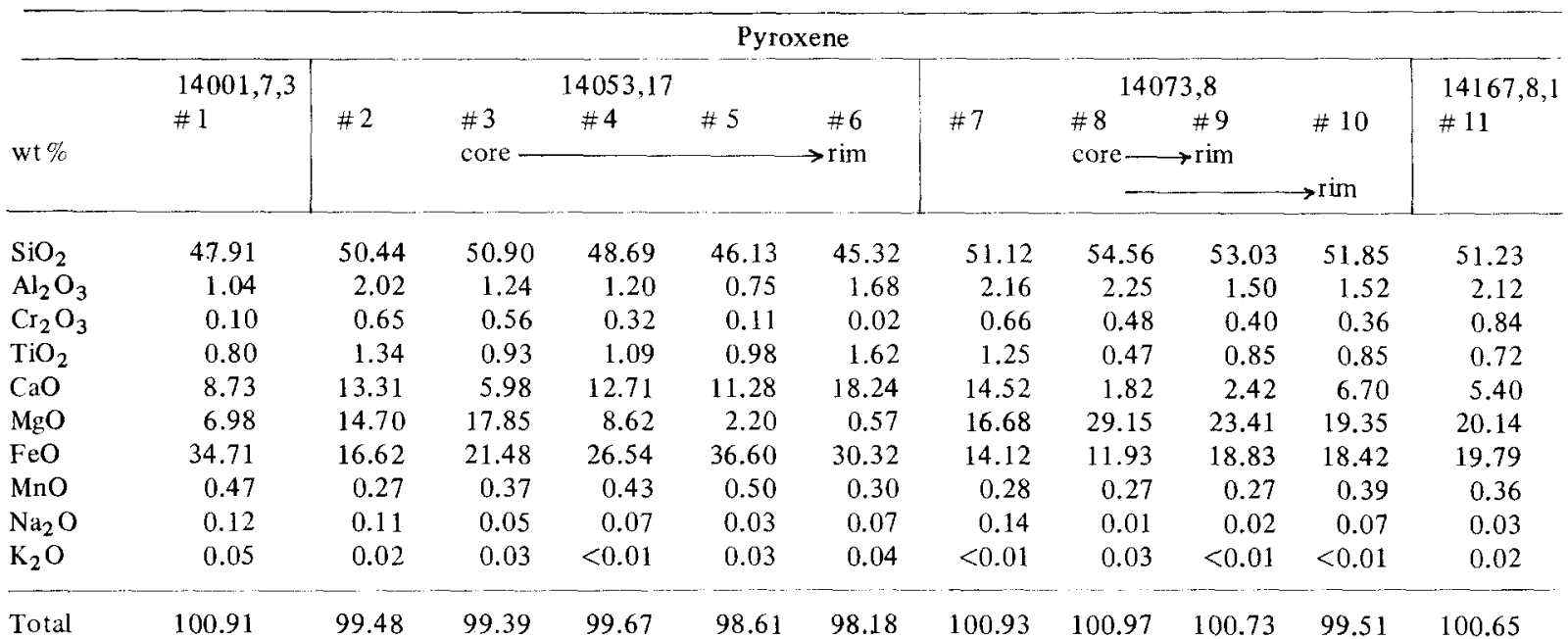

Atomic proportions

\begin{tabular}{lrrrrrrrrrrr}
$\mathrm{Si}$ & 1.93 & 1.92 & 1.94 & 1.94 & 1.96 & 1.91 & 1.90 & 1.92 & 1.94 & 1.94 & 1.90 \\
$\mathrm{Al}$ & 0.05 & 0.09 & 0.06 & 0.06 & 0.04 & 0.08 & 0.09 & 0.09 & 0.06 & 0.07 & 0.09 \\
$\mathrm{Cr}$ & $<0.01$ & 0.02 & 0.02 & 0.01 & $<0.01$ & $<0.01$ & 0.02 & 0.01 & 0.01 & 0.01 & 0.02 \\
$\mathrm{Ti}$ & 0.02 & 0.04 & 0.03 & 0.03 & 0.03 & 0.05 & 0.03 & 0.01 & 0.02 & 0.02 & 0.02 \\
$\mathrm{Ca}$ & 0.38 & 0.54 & 0.24 & 0.54 & 0.51 & 0.83 & 0.58 & 0.07 & 0.09 & 0.27 & 0.21 \\
$\mathrm{Mg}$ & 0.42 & 0.84 & 1.01 & 0.51 & 0.14 & 0.04 & 0.92 & 1.53 & 1.28 & 1.09 & 1.11 \\
$\mathrm{Fe}$ & 1.17 & 0.53 & 0.69 & 0.89 & 1.30 & 1.07 & 0.44 & 0.35 & 0.58 & 0.58 & 0.62 \\
$\mathrm{Mn}$ & 0.02 & 0.01 & 0.01 & 0.01 & 0.02 & 0.01 & 0.01 & 0.01 & $<0.01$ & 0.01 & 0.01 \\
$\mathrm{Na}$ & 0.01 & 0.01 & $<0.01$ & 0.01 & $<0.01$ & 0.01 & 0.01 & $<0.01$ & $<0.01$ & $<0.01$ & $<0.01$ \\
\hline & $4.00^{*}$ & $4.00^{*}$ & $4.00^{*}$ & $4.00^{*}$ & $4.00^{*}$ & $4.00^{*}$ & $4.00^{*}$ & $4.00^{*}$ & $4.00^{*}$ & $4.00^{*}$ & $4.00^{*}$
\end{tabular}

* Normalization factor for catatoms.

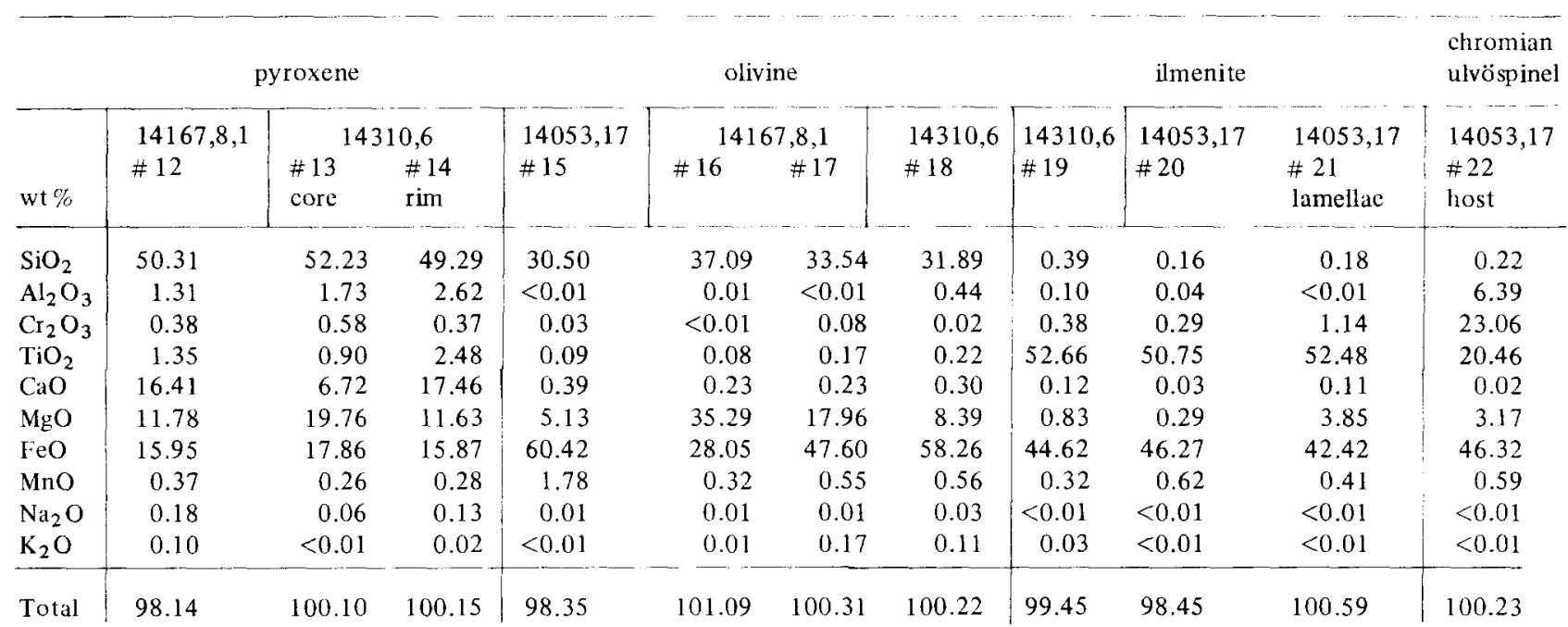


Table 4 (continued)

Atomic proportions

\begin{tabular}{l|rrr|rrrrr|rrr}
\hline $\mathrm{Si}$ & 1.96 & 1.95 & 1.89 & 1.01 & 0.98 & 0.99 & 1.01 & 0.01 & $<0.01$ & $<0.01$ \\
$\mathrm{Al}$ & 0.06 & 0.08 & 0.12 & $<0.01$ & $<0.01$ & $<0.01$ & 0.02 & $<0.01$ & $<0.01$ & $<0.01$ & 0.01 \\
$\mathrm{Cr}$ & 0.01 & 0.02 & 0.01 & $<0.01$ & $<0.01$ & $<0.01$ & $<0.01$ & 0.01 & 0.01 & 0.02 \\
$\mathrm{Ti}$ & 0.04 & 0.03 & 0.07 & $<0.01$ & $<0.01$ & $<0.01$ & 0.01 & 1.00 & 0.98 & 0.96 & 0.43 \\
$\mathrm{Ca}$ & 0.69 & 0.27 & 0.72 & 0.01 & 0.01 & 0.01 & 0.01 & $<0.01$ & $<0.01$ & $<0.01$ & $<0.01$ \\
$\mathrm{Mg}$ & 0.69 & 1.10 & 0.66 & 0.25 & 1.39 & 0.79 & 0.40 & 0.03 & 0.01 & 0.14 & 0.11 \\
$\mathrm{Fe}$ & 0.52 & 0.56 & 0.51 & 1.68 & 0.62 & 1.18 & 1.54 & 0.94 & 0.99 & 0.86 \\
$\mathrm{Mn}$ & 0.01 & 0.01 & 0.01 & 0.05 & 0.01 & 0.01 & 0.01 & 0.01 & 0.01 & 0.91 \\
$\mathrm{Na}$ & 0.02 & $<0.01$ & 0.01 & $<0.01$ & $<0.01$ & $<0.01$ & $<0.01$ & $<0.01$ & $<0.01$ & $<0.01$ & $<0.01$ \\
\hline & $4.00^{*}$ & $4.00^{*}$ & $4.00^{*}$ & $3.00^{*}$ & $3.00^{*}$ & $3.00^{*}$ & $3.00^{*}$ & $2.00^{*}$ & $2.00^{*}$ & $2.00^{*}$ & $2.00^{*}$
\end{tabular}

* Normalization factor for catatoms.

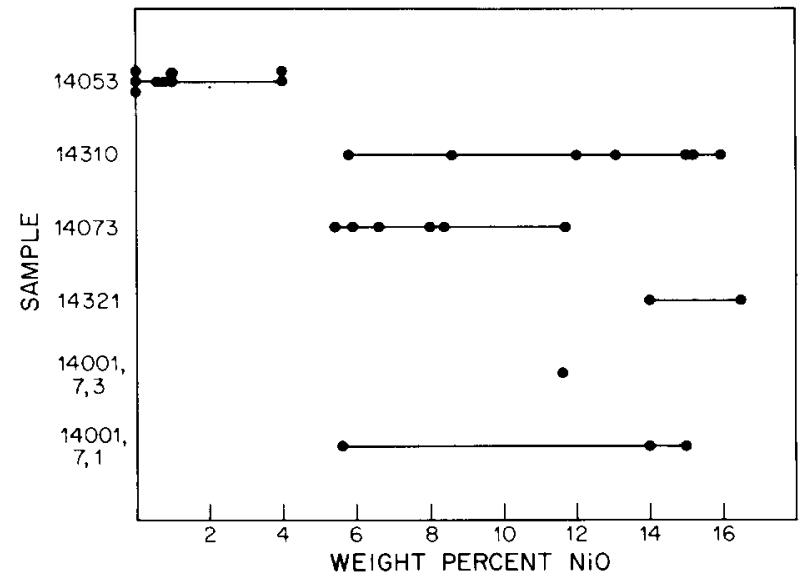

Fig. 2. Variation of the Ni content in Fe-metal grains from the studied samples. The Fe-metal in sample 14053 has a distinctly lower Ni content than in any of the other samples.

tion 14053,17 (compare plates Ia and IIa). Euhedral plagioclase laths $(\sim 0.5 \mathrm{~mm}$ long) form an interlocking or felted framework, the interstices of which contain anhedral pyroxene grains $(\sim 0.3 \mathrm{~mm})$ and mesostasis. Locally the plagioclase laths are in radial aggregates or in finer-grained patches which may represent cognate inclusions [1]. In some areas the pyroxene grains are large, and an ophitic texture is developed.

The plagioclase grains are polysynthetically twinned parallel to the laths and less commonly normal to the laths. Zoning is not pronounced and the composition is typically $\mathrm{An}_{93} \mathrm{Ab}_{6} \mathrm{Or}_{1}$ (table 3, \#7).

Relatively little variation in clinopyroxene composition is evident optically, but some grains have pigeonite cores and augite rims. The compositions of pigeonite cores (table 4, \#13) and their augite rims (table 4, \#14) do not show extensive variation in $\mathrm{Fe} / \mathrm{Mg}$. The most Fe-rich core, shown on fig. 1, has a composition very close to that of orthopyroxene, but optical properties indicate that it is pigeonite.

Opaque phases include ilmenite, troilite, and $\mathrm{Fe}$ metal. Although reported by the Preliminary Examination Team [1], neither chromian spinel nor ulvöspinel were found. Fe-metal has a Ni content ranging from 6 to $16 \mathrm{wt} \%$ (fig. 2) and occurs not only associated with troilite, but also independently.

The mesostasis is a complex of fine-grained material, including apatite, whitlockite, opaque phases, olivine and glass. An analysis of the whitlockite is included in table 6 , and the composition of the fay alitic olivine is shown in table $4, \# 18$. The glass has a wide range in composition (table 5; fig. 4) and will be discussed separately.

\subsection{Sample 14073}

Sample 14073 was a $10 \mathrm{~g}$ basalt pebble which was collected in the bottom of the trench dug in the 'smooth region' away from Cone Crater [8]. However, since part of the trench collapsed it is uncertain 


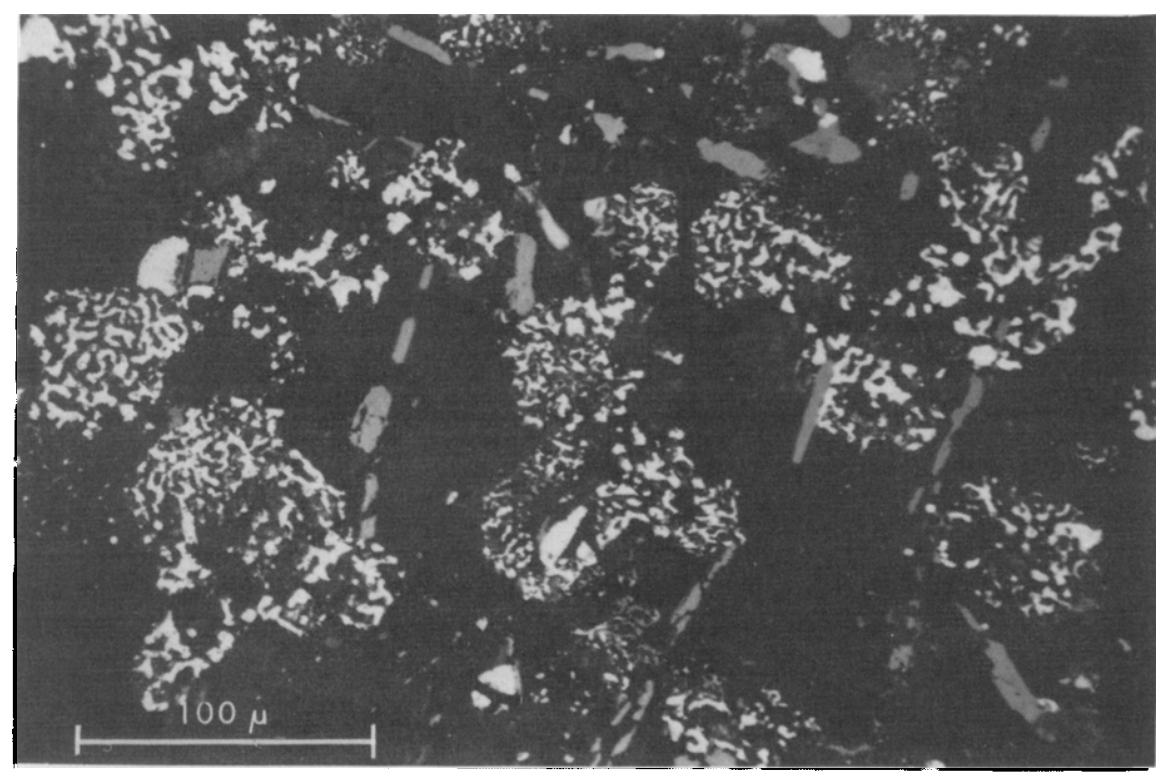

Fig. 3. Photomicrograph of the peculiar spongy masses of Fe-metal and troilite in sample 14053,17 (reflected light). The darker grey laths are ilmenite.

Table 5

Representative electron probe analyses of glass.

\begin{tabular}{|c|c|c|c|c|}
\hline & $\begin{array}{l}14310,6 \\
\text { average of } 5\end{array}$ & $\begin{array}{l}14310,6 \\
\text { average of } 2\end{array}$ & $\begin{array}{l}14053,17 \\
\text { average of } 3\end{array}$ & $\begin{array}{l}14053,7 \\
\text { globule in olivine }\end{array}$ \\
\hline $\mathrm{Na}_{2} \mathrm{O}$ & 1.00 & 0.60 & 0.32 & 0.06 \\
\hline $\mathrm{MgO}$ & 0.01 & 0.05 & 0.02 & 0.04 \\
\hline $\mathrm{Al}_{2} \mathrm{O}_{3}$ & 19.82 & 13.94 & 11.82 & 11.88 \\
\hline $\mathrm{SiO}_{2}$ & 61.32 & 77.02 & 75.87 & 82.85 \\
\hline $\mathrm{K}_{2} \mathrm{O}$ & 12.63 & 6.50 & 7.97 & 2.10 \\
\hline $\mathrm{CaO}$ & 0.77 & 0.63 & 1.14 & 1.01 \\
\hline $\mathrm{FeO}$ & 0.23 & 0.99 & 1.94 & 1.38 \\
\hline $\mathrm{BaO}$ & 3.99 & 0.23 & 0.45 & 0.20 \\
\hline Total & 99.77 & 99.96 & 99.53 & 99.52 \\
\hline \multicolumn{5}{|c|}{ Normative minerals in catatom per cent } \\
\hline or & 76.50 & 39.65 & 49.05 & 13.10 \\
\hline $\mathrm{ce}^{*}$ & 7.40 & 0.45 & 0.85 & 0.40 \\
\hline$a b$ & 9.20 & 5.55 & 3.00 & 0.55 \\
\hline an & 3.90 & 3.20 & 5.90 & 5.35 \\
\hline $\mathrm{C}$ & 0.52 & 5.21 & 0.33 & 8.69 \\
\hline en & 0.02 & 0.14 & 0.06 & 0.12 \\
\hline fs & 0.36 & 1.58 & 3.14 & 2.26 \\
\hline Q & 2.09 & 44.21 & 37.68 & 69.54 \\
\hline Total & 100.00 & 100.00 & 100.00 & 100.00 \\
\hline
\end{tabular}

* $\mathrm{BaAl}_{2} \mathrm{Si}_{2} \mathrm{O}_{8}$. 
Table 6

Electron probe analyses of phosphate minerals.

Apatite

\begin{tabular}{|c|c|c|c|c|c|c|c|c|}
\hline \multirow[b]{2}{*}{ F } & \multicolumn{2}{|c|}{$\begin{array}{c}14053,17 \\
\text { wt } \% \text { atom prop.* }\end{array}$} & \multicolumn{2}{|c|}{$\begin{array}{c}14001,7,3 \\
\text { wt } \% \text { atom prop.* }\end{array}$} & \multicolumn{2}{|c|}{$\begin{array}{l}14321,191, \mathrm{X}-1 \\
\text { wt } \% \text { atom prop.* }\end{array}$} & \multicolumn{2}{|c|}{$\begin{array}{c}14073,8 \\
\text { wt } \% \text { atom prop.* }\end{array}$} \\
\hline & 3.11 & 0.85 & 3.96 & 1.08 & 3.14 & 0.86 & 3.03 & 0.86 \\
\hline $\mathrm{Cl}$ & 0.07 & 0.10 & 0.04 & 0.01 & 0.41 & 0.06 & 0.06 & 0.01 \\
\hline $\mathrm{SiO}_{2}$ & 1.33 & 0.11 & 0.40 & 0.03 & 2.62 & 0.23 & 1.01 & 0.09 \\
\hline $\mathrm{P}_{2} \mathrm{O}_{5}$ & 39.79 & 2.90 & 40.56 & 2.96 & 37.66 & 2.78 & 37.90 & 2.86 \\
\hline $\mathrm{Na}_{2} \mathrm{O}$ & $<0.01$ & $<0.01$ & $<0.01$ & $<0.01$ & $<0.01$ & $<0.01$ & $<0.01$ & $<0.01$ \\
\hline $\mathrm{MgO}$ & $<0.01$ & $<0.01$ & $<0.01$ & $<0.01$ & $<0.01$ & $<0.01$ & $<0.01$ & $<0.01$ \\
\hline $\mathrm{CaO}$ & 53.79 & 4.96 & 53.95 & 4.99 & 52.70 & 4.92 & 52.45 & 5.01 \\
\hline $\mathrm{FeO}$ & 0.15 & 0.01 & 0.01 & 0.01 & 0.54 & 0.04 & 0.11 & 0.01 \\
\hline $\mathrm{Al}_{2} \mathrm{O}_{3}$ & $<0.01$ & $<0.01$ & $<0.01$ & $<0.01$ & $<0.01$ & $<0.01$ & 0.03 & $<0.01$ \\
\hline $\mathrm{Y}_{2} \mathrm{O}_{3}$ & 0.39 & 0.02 & 0.20 & $<0.01$ & 0.64 & 0.03 & 0.50 & 0.03 \\
\hline $\mathrm{La}_{2} \mathrm{O}_{3}$ & $<0.01$ & $<0.01$ & $<0.01$ & $<0.01$ & $<0.01$ & $<0.01$ & $<0.01$ & $<0.01$ \\
\hline $\mathrm{Ce}_{2} \mathrm{O}_{3}$ & $<0.01$ & $<0.01$ & $<0.01$ & $<0.01$ & 0.12 & $<0.01$ & $<0.01$ & $<0.01$ \\
\hline $\mathrm{Nd}_{2} \mathrm{O}_{3}$ & $<0.01$ & $<0.01$ & $<0.01$ & $<0.01$ & $<0.01$ & $<0.01$ & $<0.01$ & $<0.01$ \\
\hline Total & 98.63 & & 99.11 & & 97.83 & & 95.10 & \\
\hline
\end{tabular}

* Cations normalized to 8 .

Whitlockite

\begin{tabular}{|c|c|c|c|c|c|c|c|c|}
\hline \multirow[b]{2}{*}{$\mathrm{F}$} & \multicolumn{2}{|c|}{$\begin{array}{c}14053,17 \\
\text { wt } \% \text { atom prop. } * *\end{array}$} & \multicolumn{2}{|c|}{$\begin{array}{c}14001,7,3 \\
\text { wt \% atom prop.** }\end{array}$} & \multicolumn{2}{|c|}{$\begin{array}{c}14310,6 \\
\text { wt \% atom prop.** }\end{array}$} & \multicolumn{2}{|c|}{$\begin{array}{c}14001,7,1 \\
\text { wt } \% \text { atom prop.** }\end{array}$} \\
\hline & $<0.01$ & $<0.01$ & $<0.01$ & $<0.01$ & $<0.01$ & $<0.01$ & 0.03 & 0.01 \\
\hline $\mathrm{Cl}$ & $<0.01$ & $<0.01$ & $<0.01$ & $<0.01$ & $<0.01$ & $<0.01$ & 0.01 & $<0.01$ \\
\hline $\mathrm{SiO}_{2}$ & 0.45 & 0.03 & 0.34 & 0.02 & 0.38 & 0.02 & 0.38 & 0.02 \\
\hline $\mathrm{P}_{2} \mathrm{O}_{5}$ & 41.45 & 2.01 & 41.96 & 2.07 & 41.78 & 2.04 & 43.65 & 2.01 \\
\hline $\mathrm{Na}_{2} \mathrm{O}$ & $<0.01$ & $<0.01$ & 0.18 & 0.02 & $<0.01$ & $<0.01$ & 0.24 & 0.03 \\
\hline $\mathrm{MgO}$ & 1.47 & 0.13 & 0.83 & 0.07 & 1.27 & 0.11 & 2.98 & 0.24 \\
\hline $\mathrm{CaO}$ & 40.33 & 2.48 & 41.26 & 2.57 & 40.77 & 2.52 & 42.83 & 2.49 \\
\hline $\mathrm{FeO}$ & 2.89 & 0.14 & 3.51 & 0.17 & 3.46 & 0.17 & 1.43 & 0.06 \\
\hline $\mathrm{Al}_{2} \mathrm{O}_{3}$ & $<0.01$ & $<0.01$ & $<0.01$ & $<0.01$ & $<0.01$ & $<0.01$ & 0.04 & $<0.01$ \\
\hline $\mathrm{Y}_{2} \mathrm{O}_{3}$ & 3.80 & 0.14 & 1.48 & 0.06 & 2.40 & 0.09 & 2.49 & 0.09 \\
\hline $\mathrm{La}_{2} \mathrm{O}_{3}$ & 0.43 & 0.01 & $<0.01$ & $<0.01$ & 0.11 & $<0.01$ & 0.70 & 0.01 \\
\hline $\mathrm{Ce}_{2} \mathrm{O}_{3}$ & 2.53 & 0.05 & 1.47 & 0.03 & 2.37 & 0.05 & 2.27 & 0.04 \\
\hline $\mathrm{Nd}_{2} \mathrm{O}_{3}$ & 0.55 & 0.01 & 0.25 & 0.01 & 0.43 & 0.01 & 1.34 & 0.03 \\
\hline Total & 93.90 & & 91.28 & & 92.97 & & 98.39 & \\
\hline
\end{tabular}

** Cations normalized to 5 .

that it was actually buried [8]. It was studied in polished thin section 14073,8 which has an area of about $175 \mathrm{~mm}^{2}$.

The section is of a subophitic, intergranular to intersertal, orthopyroxene basalt (plate IIb). It is composed predominantly of plagioclase $(\sim 50 \%)$ clinopyroxene $(\sim 25 \%)$ and orthopyroxene $(\sim 20 \%)$ with minor ilmenite $(\sim 2 \%)$, troilite, Fe-metal, mesostasis and other minor phases (table 2). The presence of orthopyroxene distinguishes this rock from the others studied and from the Apollo 11 and 12 samples. Despite the presence of orthopyroxene, the grain size and texture is nearly identical to that of 14310 , characterized by a felted, plagioclase-lath framework and containing similar cognate inclusions (plates IIa and IIb). Locally, the pyroxene is coarser 


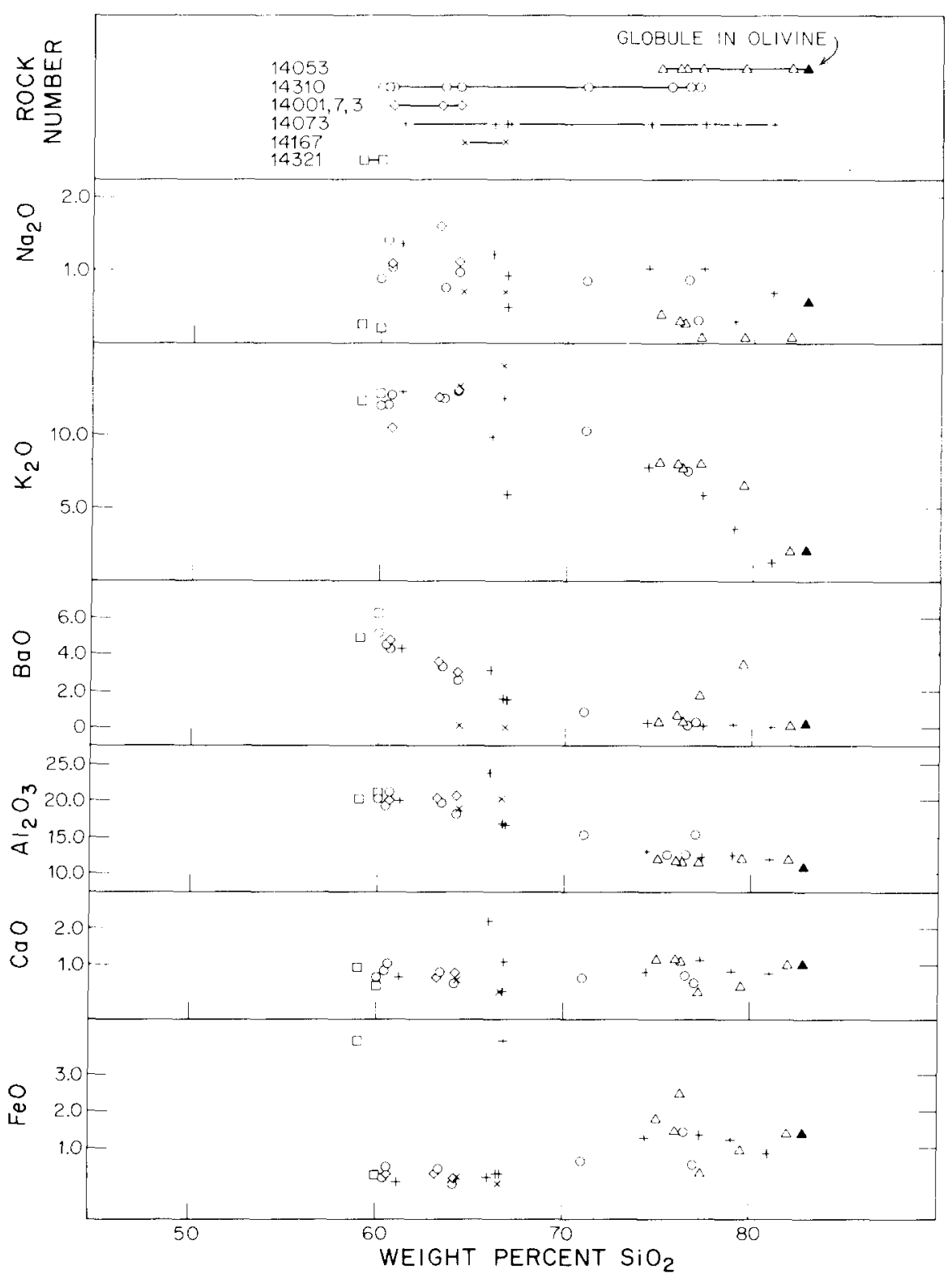

Fig. 4. Variation diagram of glass in the studied samples. Analy'ses are of both glass in the thin sections and glass from the 'quintessence' separates of samples 14053,14073 , and 14310 .

grained enclosing the plagioclase and the texture becomes ophitic. The observed shock features are described in section 3.13 .

Polysynthetic twinning parallel to the laths is common in the plagioclase. Zoning is not pronounced and the composition is typically $\mathrm{An}_{94} \mathrm{Ab}_{5} \mathrm{Or}_{1}$ (table 3 , \#5). However, a few grains show zoning reversals at a distinct interface within the crystals.

Unlike 14310,6 nearly half the pyroxene in 14073,8 is or thopyroxene, but the compositional variation of 
the pyroxene in 14310,6 and 14073,8 is grossly similar (fig. 1; table 4). Because the grains are irregular, it is difficult to discern the growth direction. However, both orthopyroxene and augite occur in some grains and in other grains or thopyroxene cores are rimmed by more $\mathrm{Fe}$-rich orthopyroxene and by more Fe-rich pigeonite. As in thin section 14310,6 there does not appear to be extensive $\mathrm{Fe} / \mathrm{Mg}$ variation in'the clinopyroxene.

Opaque phases include ilmenite, troilite, and $\mathrm{Fe}-$ metal with a Ni content ranging from 5 to $12 \mathrm{wt} \%$ (fig. 2). The larger ilmer te grains commonly contain lensoidal inclusions of gl ss and associated minor phases.

The mesostasis contains opaque phases, apatite, whitlockite, and glass. The glass is predominantly brown and rich in $\mathrm{K}_{2} \mathrm{O}$ and $\mathrm{BaO}$. It exhibits a wider range in composition than in any of the other studied samples.

\subsection{Sample $14001,7,3$}

Sample 7,3 was a $0.088 \mathrm{~g}$ fragment from the coarse fines of the contingency sample $(14001,7)$ collected in the 'smooth region' away from Cone Crater [8]. It was studied in two micro-thin sections both with areas of about $0.25 \mathrm{~mm}^{2}$. The fragment is an ophitic, intergranular basalt composed predominantly of plagioclase feldspar $(\sim 75 \%)$ and clinopyroxene $(\sim 20 \%)$ with minor $\mathrm{Fe}$-metal, iroilite, ilmenite, mesostasis and other minor phases (plate Ib; table 2). The texture is much like that of 14310 , but such a fragment could be derived from selected portions of 14053,17 . Mild shock features were observed both in the thin sections and in the fragment before thin section preparation. These features are discussed in sect. 3.13.

Pyroxene compositions are indicated on fig. 1 and in table $4, \# 1$. Both augite and pigeonite are present, and substantial $\mathrm{Fe}$-enrichment trends are evident (fig. 1). Plagioclase compositions are predominantly about $\mathrm{An}_{95} \mathrm{Ab}_{5}$ (table 3), but more sodic rims occur $\left(\mathrm{An}_{82} \mathrm{Ab}_{16} \mathrm{Or}_{2}\right)$.

Fe-metal is common, but only one grain vas large enough for quantitative analysis and yielded a $\mathrm{Ni}$ content of $12 \mathrm{wt} \%$ (fig. 2).

Despite the small sample size, glass is so abundant as to permit its separation for isotopic investigation [2]. The glass is rich in $\mathrm{K}_{2} \mathrm{O}$ and $\mathrm{BaO}$. The chemical composition of the glass, Fe-metal, U-Th-rich phases and other minor phases is discussed in later sections.

\subsection{Sample $14321,191, X-1$}

Sample X-1 is a $0.16 \mathrm{~g}$ fragment taken from "Big Bertha", a 8996 g breccia sample collected near Cone Crater rim [8]. It was studied in micro-thin sections with areas of $0.20 \mathrm{~m}^{2}$ and $0.15 \mathrm{~mm}^{2}$. The fragment is a subophitic, intergranular, basalt composed predominantly of plagioclase $(\sim 70 \%)$ and clinopyroxene $(\sim 25 \%)$ with minor Fe-metal, troilite, ilmenite, mesostasis and other minor phases (table 2). The texture more closely resembles the texture of 14310,6 than of 14053,17 , but could be derived from portions of either (fig. 5). Mild shock features vere observed and a re discussed in sect. 3.13.

A limited number of pyroxene analyses aie show' in fig. 1 and suggest a rather limited range of pyroxene composition, but only a few grains of pyroxene were present in the sections. Binocular microscope examination of the pyroxene separate used for $\mathrm{Rb} / \mathrm{Sr}$ analysis show a greater range of color (pale yellow to dark brown) than is suggested by the elect on probe analyses.

Plagioclase is polysynthetically tr inned with compositions ranging from $\mathrm{An}_{93} \mathrm{Ab}_{7}$ to $\mathrm{In}_{87} \mathrm{Ab}_{12} \mathrm{Or}_{1}$.

$\mathrm{Fe}-\mathrm{metal}$ is common and analyse: yielded a $\mathrm{Ni}$ content ranging from 14 to $17 \mathrm{wt} \%$ (fig. 2).

The chemical composition of glass is discussed later.

\subsection{Sample $14167,8,1$}

Sample 8,1 was an $0.067 \mathrm{~g}$ fragment from the coarse fines of the comprehensive sample $(14167,8)$ collected from the 'smooth region' away from Cone Crater [8]. It was studied in a microthin section with an area of about $1 \mathrm{~mm}^{2}$.

The fragment is an ophitic, olivine basalt with laths $(\sim 0.1 \mathrm{~mm})$ of plagioclase $(\sim 35 \%)$ enclosed in larger grains $(\sim 0.25 \mathrm{~mm})$ of clinopyroxene $(\sim 30 \%)$ and olivine $(\sim 30 \%)$. Minor minerals include Fe-metal, troilite, ilmenite, mesostasis and other phases (table 2). Shock-induced features were observed and are discussed in sect. 3.13.

Plagioclase occurs in pol synthetically twinned laths with a composition of tbout $\mathrm{An}_{90} \mathrm{Ab}_{10}$.

The presence of abundar primary olivine distinguishes this fragment from the others studied. Most of the olivine has a composition of about $\mathrm{Fa}_{30} \mathrm{Fo}_{70}$, but much more $\mathrm{Fe}$-rich olivine occurs as cores in pyroxene (fig. 1). Olivine occurs both as cores in pigeonite (table $4, \# 16, \# 11$ ) and as cores in 


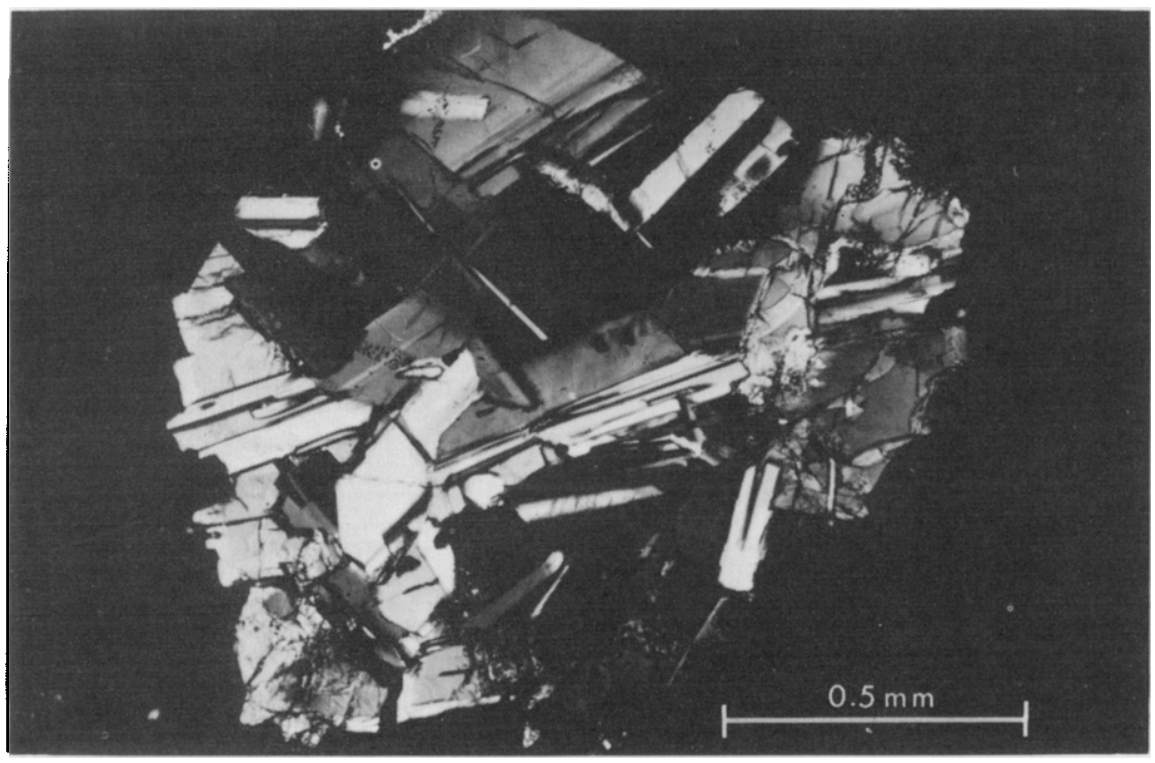

Fig. 5. Photomicrograph of section $14321,191, \mathrm{X}-1$ (crossed nicols).

augite (table 4, \#17,\#12). Neither the augite nor pigeonite show extensive variation in $\mathrm{Fe} / \mathrm{Mg}$.

The mesostasis in this sample is not well developed and only a small amount of glass is present (fig. 4).

\subsection{Sample 14001,7,1}

Sample 7,1 is an $0.062 \mathrm{~g}$ fragment from the coarse fines of the contingency sample $(14001,7) \mathrm{col}-$ lected in the 'smooth region' away from Cone Crater [8]. The fragment was examined and removed for study because it is the most distinctive lithic type in sample 14001,7 [9]. It is a dark-gray vesicular rock with a sugary texture [2]. Spherical vesicles and vugs are common and are lined with crystals of ilmenite, feldspar, and troilite [9].

The fragment was studied in two micro-thin sections with areas of about $0.6 \mathrm{~mm}^{2}$ and $0.7 \mathrm{~mm}^{2}$. It is a shocked rock with a very fine-grained texture which was shock induced. However, the preshocked character can be discerned by combining observations in reflected light with information from electron beam scans. The original rock was a subophitic, orthopyroxene basalt with an average grain size of about $0.03 \mathrm{~mm}$ and composed predominantly of pyroxene ( $\sim 45 \%)$, feldspar and mesostasis (?) (together approximately $55 \%)$, and whitlockite $(\sim 3 \%)$ with minor amounts of ilmenite, Fe-metal, troilite, and other phases (table 2).

Pyroxene compositions are shown on fig. 1 and suggest the presence of augite, pigeonite, and orthopyroxene. Both orthopyroxene and clinopyroxene were identified optically, but no estimates of their relative abundances could be made.

Electron beam scan photographs indicate that many of the areas analysed are intimate mixtures of Ca-rich and K-rich feldspar. Consequently, the analyses are probably of mixtures of phases and were discarded. A plagioclase analysis was obtained with a composition of $\mathrm{An}_{95} \mathrm{Ab}_{5}$ and two were obtained with compositions of about $\mathrm{An}_{80} \mathrm{Ab}_{18} \mathrm{Or}_{2}$.

$\mathrm{Fe}-\mathrm{metal}$ has an $\mathrm{Ni}$ content ranging from 5 to 15 wt $\%$ (fig. 2). Other minor phases were not analyzed.

Fig. 6 illustrates the preshocked character of the rock. It was prepared by comparing reflected light photographs with electron beam scan photographs for $\mathrm{Mg}, \mathrm{K}, \mathrm{Fe}, \mathrm{Ti}, \mathrm{Ca}, \mathrm{Al}, \mathrm{Na}, \mathrm{Zr}, \mathrm{S}, \mathrm{Ba}, \mathrm{P}, \mathrm{Y}$ and $\mathrm{Cl}$. This particular area is believed to represent a shocked mesostasis area, because of the abundance of K-rich phase(s). These areas consist of low birefringent, somewhat fibrous appearing aggregates of K-rich and Ca-rich feldspar that possibly represent recrystallization after the shock event. The K-rich areas are not 


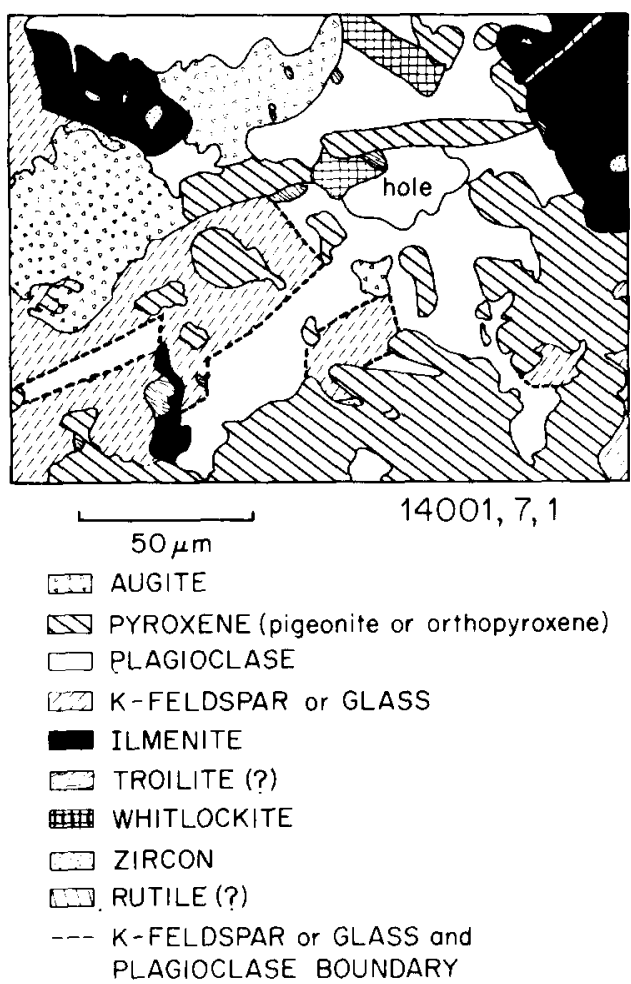

Fig. 6. A section of sample $14001,7,1$ prepared by comparing reflected light photomicrographs and electron beam scan photographs.

completely isotropic. No large completely isotropic areas were observed in this sample.

Ilmenite shows no obvious shock effects, and preserves its lath shape and globular silicate inclusions. Pyroxene grains show undulose extinction, some polygonization, and rare lamellar structures. Although both plagioclase and pyroxene show shock-induced fractures, the original grain morphologies have not been seriously altered as are shown in fig. 6 .

The mineralogy, the preshocked texture, and the shock effects in this rock are similar to those found in Luny Rock 1 from Apollo 11 [6]. However, the plagioclase grains in Luny Rock 1 are shock-isotropized (maskelynite), and the pyroxene and ilmenite crystals are fractured and somewhat granulated. These features suggest that Luny Rock 1 was subjected to greater shock pressure. .

The presence of spherical vesicles lined with crystals presents a distinct problem in interpretation. Based on the visible shock features, the shock pressures were not sufficient to produce vesiculation [13]. However, if the vesicles were pre-shock features of the basalt it is difficult to understand their apparently undeformed survival.

\subsection{Pyroxene and olivine}

The pyroxene and olivine in some of the Apollo 14 samples display compositional and structural features very similar to those in Apollo 11 and 12 samples, but several of the samples have pyroxene and olivine which are quite distinctive.

Analytical data on the pyroxenes is summarized on fig. 1 and in table 4. Pyroxene in the Apollo 11 samples is predominantly augite which displays extensive $\mathrm{Fe}$ enrichment in single grains. The Apollo 12 samples contain both pigeonite and augite in complicated intergrowths, but generally limited Fe enrichment. Pyroxene in sample 14053,17 displays extensive Fe enrichment in single grains, similar to Apollo 11 pyroxene (fig. 1). Pyroxene in samples 14001,7,3; $14321,191, X-1$ and 14310,6 do not display extensive Fe enrichment, but contain complicated in tergrowths of pigeonite and augite.

Sample 14073,8 contains abundant orthopyroxene. Such rocks have been reported by many investigators as lithic fragments in the soils and breccias of both Apollo 11 and 12, and orthopyroxene grains are common in the soil samples $[6,14-17]$. However, sample 14073 is the first rock sample containing orthopyroxene. Sample 14001,7,1 also contains orthopyroxene, but is similar to Luny Rock 1 [6] and other lithic fragments (for example 17).

Sample 14167,8,1 contains Mg-rich olivine as an abundant primary phase and is somewhat like Apollo 11 sample 10020 [6]. The fayalitic olivine in sample 14053,17 is distinctive as it has a high $\mathrm{MnO}$ content (table 4, \#15).

The size of the triangles on fig. 1 indicates the total $\mathrm{CaTi}\left(\mathrm{Al}_{2} \mathrm{O}_{6}\right), \mathrm{CaCr}\left(\mathrm{AlSiO}_{6}\right), \mathrm{CaAl}\left(\mathrm{AlSiO}_{6}\right)$ and $\mathrm{NaAl}\left(\mathrm{Si}_{2} \mathrm{O}_{6}\right)$ substitution in the pyroxenes. The principal substitution in the Apollo 11 pyroxenes was $\mathrm{CaTi}\left(\mathrm{Al}_{2} \mathrm{O}_{6}\right)$ and $\mathrm{CaCr}\left(\mathrm{AlSiO}_{6}\right)$, but $\mathrm{CaAl}\left(\mathrm{AlSiO}_{6}\right)$ substitution was important in the pyroxene of the Apollo 12 samples. The analyses of pyroxene from these samples are most like the Apollo 12 samples and contain more $\mathrm{Cr}$ and $\mathrm{Al}$ than necessary to balance the $\mathrm{Ti}$ as $\mathrm{CaTi}\left(\mathrm{Al}_{2} \mathrm{O}_{6}\right)$. 


\subsection{Glass}

Glass occurs interstitial to the major phases and also trapped within the major phases. It was found in all the samples except $14001,7,1$ in which material similar in composition to the glasses occurs but is anisotropic. Only of glass in the mesostasis of thin sections and in grain mounts of the 'quintessence' separates used for the $\mathrm{Rb} / \mathrm{Sr}$ analyses of 14053 , 14073 and 14310 was analyzed. The analyses are shown on the variation diagram (fig. 4) and averaged analyses from 14053 and 14310 are given in table 5 .

Two chemically different, but optically similar glasses are present. The first type is rich in $\mathrm{SiO}_{2}$ and poor in $\mathrm{K}_{2} \mathrm{O}$ and $\mathrm{BaO}\left(\mathrm{SiO}_{2} 70\right.$ to $82 \mathrm{wt} \%$ ), and the second type is poor in $\mathrm{SiO}_{2}$ and rich in $\mathrm{K}_{2} \mathrm{O}$ and $\mathrm{BaO}$ $\left(\mathrm{SiO}_{2} 59\right.$ to $70 \mathrm{wt} \%$ ) (table 5). All of the glass in 14053 is $\mathrm{SiO}_{2}$-rich glass. This sample also contains glass globules enclosed in olivine within the mesostasis. These globules are the most $\mathrm{SiO}_{2}$-rich glass analyzed $\left(\mathrm{SiO}_{2} 82.5 \mathrm{wt} \%\right)$, and are much higher in normative quartz and corundum than all the other glasses. Both $\mathrm{SiO}_{2}$-rich and $\mathrm{SiO}_{2}$-poor glass is present in sample 14310 , but the $\mathrm{SiO}_{2}$-poor glass predominates. Although sample 14310 contains both glass types, the overlap in the range of $\mathrm{SiO}_{2}$ content of this sample and in 14053 is small. Sample 14073 exhibits a continuous range in $\mathrm{SiO}_{2}$ content from 61 to $81 \mathrm{wt} \%$. Samples $14001,7,3 ; 14167,8,1$ and $14321,191, \mathrm{X}-1$ contain only $\mathrm{SiO}_{2}$-poor glass and in this respect are similar to sample 14310.

Despite the complex mineral separation procedures in preparing samples for $\mathrm{Rb} / \mathrm{Sr}$ analyses, the glass in the 'quintessence' grain mounts shows the same compositional range as the glass in the mesostasis of the respective thin sections.

\subsection{Fe-metal}

Metallic iron occurs in all the samples. As in the Apollo 12 samples and unlike the Apollo 11 samples metallic iron is not intimately associated with troilite and grains have a high and variable $\mathrm{Ni}$ content. A limited number of analyses (fig. 2) suggest that the $\mathrm{Ni}$ content of sample 14053 is lower than that of the other samples, in which the Ni content ranges from 5 to $17 \mathrm{wt} \%$.

\subsection{Phosphate minerals}

Except for sample $14001,7,1$ both apatite and whitlockite were found in those samples in which they were looked for systematically. Representative analyses are given in table 6 . They typically occur as small needles or granules in the mesostasis except in sample $14001,7,1$ where whitlockite crystals up to $0.2 \mathrm{~mm}$ are present. The compositions are like those found in other lunar samples $[6,7,18]$. The apatite is a chlorofluorapatite with a low content of rare earth elements. As in the analyses of whitlockite which we reported earlier [6], the summations are low and the substitution of $\mathrm{Na}^{+1}$ for $\mathrm{Ca}^{2+}$ and $\mathrm{Si}^{4+}$ for $\mathrm{P}^{5+}$ does not appear to balance the substitution of $(\mathrm{REE})^{3+}$ for $\mathrm{Ca}^{2+}$. The low summations may be due in part to the presence of $U$ and Th [19], Li [18], and other REE, or simply be an analy tical error due to the small grain size [20]. Fission track work [21] indicates the presence of $U$ and $T h$ in phosphate grains from $14001,7,3$, 14310 and 14053,17 .

\subsection{Uranium and thorium rich phases}

Preliminary fission track work indicates that U-Thrich phases are abundant in samples $14001,7,3$ and 14310,6 , but not in 14053,17 [21]. In samples $14001,7,3$ and 14310,6 much of the $\mathrm{U}$ and Th is present in phosphate minerals and interstitial material. In addition, distributed throughout the rock are tight clusters of tracks which suggest the presence of a phase rich in $U$ and Th. Analyses of this phase in sample 14001,7,3 are given in table 7. It is rich in $\mathrm{Ti}$, $\mathrm{Zr}$, and $\mathrm{Fe}$ and contains $\mathrm{Si}, \mathrm{Ca}, \mathrm{Nb}, \mathrm{U}, \mathrm{Th}, \mathrm{Pb}, \mathrm{Y}$ and REE. It occurs as small $(<5 \mu)$ opaque grains intimately associated with other opaque minerals. The summations are very low, presumably due to the very small, hard grains which developed curved surfaces when polished [20]. Furthermore, we did not analyze for elements in material surrounding the grains. The analyses, however, appear to represent two different compositions. In addition they appear to differ from both phase A of Frick et al. [22] and phase $\beta$ of Haines et al. [19], analyses of which are also given in table 7 . It is notable that the atomic $\mathrm{Th} / \mathrm{U}$ in analyses 1 and 2 differs markedly from that of analy ses 3 and 4. Assuming that all the $\mathrm{Pb}$ is radiogenic, ages have been calculated and are given in table 7. Because of the analy tical error and lack of isotopic data, no precise age significance can be attached to these ages. The errors cited are simply those for the counting statistics. 
Table 7

Electron probe analyses and calculated model ages for $\mathrm{U}$ and $\mathrm{Th}$ rich phases.

\begin{tabular}{|c|c|c|c|c|c|c|}
\hline $\mathrm{wt} \%$ & $\begin{array}{l}14001,7,3 \\
\# 1\end{array}$ & $\begin{array}{l}14001,7,3 \\
\# 2\end{array}$ & $\begin{array}{l}14001,7,3 \\
\# 3\end{array}$ & $\begin{array}{l}14001,7,3 \\
\# 4\end{array}$ & $\begin{array}{l}\text { Phase } \beta^{*} \\
\# 5\end{array}$ & $\begin{array}{l}\text { Phase } A^{* *} \\
\# 6\end{array}$ \\
\hline $\mathrm{SiO}_{2}$ & 7.0 & 14.7 & 13.7 & 13.5 & 2.0 & 1.1 \\
\hline $\mathrm{CaO}$ & 3.8 & 3.3 & 6.0 & 5.8 & 2.9 & 13.8 \\
\hline $\mathrm{TiO}_{2}$ & 12.9 & 12.2 & 10.4 & 9.8 & 22.1 & 19.5 \\
\hline $\mathrm{FeO}$ & 17.3 & 19.5 & 11.3 & 9.2 & 13.8 & 42.8 \\
\hline $\mathrm{Y}_{2} \mathrm{O}_{3}$ & 2.9 & 2.4 & 1.1 & 1.1 & 8.9 & 2.6 \\
\hline $\mathrm{ZrO}_{2}$ & 23.5 & 16.1 & 34.4 & 34.1 & 17.2 & 17.4 \\
\hline $\mathrm{Nb}_{2} \mathrm{O}_{5}$ & 3.6 & 3.3 & 2.4 & 2.8 & 7.9 & - \\
\hline $\mathrm{La}_{2} \mathrm{O}_{3}$ & 0.2 & 0.3 & $<0.1$ & $<0.1$ & 0.2 & - \\
\hline $\mathrm{Ce}_{2} \mathrm{O}_{3}$ & 1.8 & 1.5 & 0.7 & 0.4 & 1.6 & - \\
\hline $\mathrm{Nd}_{2} \mathrm{O}_{3}$ & 1.3 & 1.2 & 0.4 & 0.6 & 0.9 & - \\
\hline $\mathrm{Gd}_{2} \mathrm{O}_{3}$ & 0.4 & 0.3 & 0.2 & 0.3 & - & - \\
\hline $\mathrm{Er}_{2} \mathrm{O}_{3}$ & 0.6 & 0.6 & 0.8 & 0.5 & - & - \\
\hline $\mathrm{PbO}$ & 1.2 & 1.3 & 2.3 & 2.6 & 4.2 & - \\
\hline $\mathrm{ThO}_{2}$ & 3.4 & 5.0 & 3.0 & 3.0 & 3.5 & - \\
\hline $\mathrm{UO}_{2}$ & 0.6 & 0.9 & 2.3 & 2.4 & 3.6 & - \\
\hline Other & - & - & - & - & 2.2 & 1.2 \\
\hline Total & 80.5 & 82.6 & 89.0 & 86.1 & 91.0 & 98.4 \\
\hline $\mathrm{Pb} / \mathrm{U}^{* * *}$ & $2.4 \pm 0.6$ & $1.8 \pm 0.3$ & $1.3 \pm 0.3$ & $1.3 \pm 0.1$ & $1.5 \pm 0.8$ & \\
\hline $\mathrm{Th} / \mathrm{U}^{* * *}$ & $5.8 \pm 1.3$ & $5.7 \pm 0.9$ & $1.3 \pm 0.3$ & $1.3 \pm 0.1$ & $1.1 \pm 0.4$ & \\
\hline Age $\mathrm{AE}$ & $4.0 \pm 0.6$ & $3.2 \pm 0.5$ & $3.6 \pm 0.5$ & $3.8 \pm 0.2$ & & \\
\hline
\end{tabular}

* Haines et al. [19].

** Frick et al. [22] .

*** Atomic ratios.

In contrast to the above sample, sample 14053,17 has only a few weak clusters of tracks indicating a low $\mathrm{U}$ and $\mathrm{Th}$ content and suggesting that phases rich in these elements are absent.

With larger grains and more accurate analyses, the $U$ and Th-rich phases in these crystalline rocks may be used to determine more accurate 'microprobe ages' [22]. The presence of these phases suggests that caution must be exercised in preparation of material for $\mathrm{U}-\mathrm{Th}-\mathrm{Pb}$ isotopic analysis and in interpretation of analytical results.

Another minor phase found in samples $14001,7,3$, 14310,6 and 14073,8 is a transparent reddish-orange mineral which occurs as small platelets as large as $5 \times 5 \times 1 \mu$. All the grains which we observed are oriented at an angle to the surface of the section and present too small a surface area for analysis. However, wavelength scans indicate that it is an $\mathrm{Fe}-\mathrm{Ti}-\mathrm{Zr}$ silicate without $\mathrm{Nb}$ and $\mathrm{REE}$.

\subsection{Shock features}

In thin sections 14053,17 and 14310,6 the pyroxene grains exhibit irregular fractures. These, however, may have been induced during preparation of the thin sections. Distinctive features, observed in thin section 14073,8 which are suggestive of shock metamorphism, include extreme, irregularly fractured pyroxene, parallel-planar fractures in plagioclase, bent twin planes in plagioclase, and pressure-induced plagioclase twinning.

Fragments $14001,7,3 ; 14167,8,1$ and 14321,191 , $\mathrm{X}-1$ were examined for shock-induced features prior to thin section preparation. In all cases they are surrounded by a very friable, milky-white aggregate of plagioclase which is distinct from the usual clear lunar plagioclase grains. This feature is probably shock induced and the fragments may represent the most weakly shocked kernels of the lithic fragments.

The most highly shocked fragment examined is 
$14001,7,1$. As noted previously plagioclase grains have undulose extinction, show some polygonization and rare lamellar structures and pyroxene grains have undulose extinction and some polygonization.

\section{Sample comparison and discussion}

Isotopic investigations on these samples by our colleagues $[2,3]$ indicate that they are distinctly older than the Apollo 11 and Apollo 12 basalts and slightly younger than rock 12013 [18]. Moreover, the analyzed Apollo 14 basaltic rocks fall into two groups with $\mathrm{Rb} / \mathrm{Sr}$ crystallization ages of 3.88 and $3.95 \mathrm{AE}$ and with distinct initial $\left({ }^{87} \mathrm{Sr} /{ }^{86} \mathrm{Sr}\right.$ ) values (table 1$)$. The ${ }^{40} \mathrm{Ar}-{ }^{39} \mathrm{Ar}$ ages agree closely and there is a suggestion that the older age group has a younger ${ }^{38} \mathrm{Ar}-{ }^{37} \mathrm{Ar}$ cosmic ray exposure age.

Fortunately, each of these two groups contains one of the two large crystalline rock samples and these two rocks are petrologically distinct as discussed by the Preliminary Examination Team [1] . We shall attempt to define distinguishing petrologic features of these samples which might be determinable in the many lithic fragments on which isotopic investigations cannot be undertaken. It is important, however, to note that the fragments which we examined were probably biased toward the more coherent portions of the samples. Consequently, the fragments described may not represent the entire sample used for isotopic work.

Samples 14310 and 14053 , as represented by the thin sections available to us, are distinguished by a number of following characteristics:

(1) Thin section 14310,6 has a subophitic texture with rather elongate plagioclase laths forming a randomly oriented framework to the interstitial pyroxene and mesostasis, whereas thin section 14053,17 has an ophitic texture more typical of Apollo 11 and 12 rocks. In addition the spongy masses of opaque minerals in 14053,17 are quite distinctive.

(2) Thin section 14310,6 has a higher plagioclase content than 14053,17 .

(3) Thin section 14053,17 has a pronounced Feenrichment trend in the pyroxene (fig. 1), a more pronounced $\mathrm{Na}$-enrichment trend in the plagioclase than 14310,6 .

(4) The mesostasis glass in 14053,17 is distinctly richer in $\mathrm{SiO}_{2}$ and poorer in $\mathrm{K}_{2} \mathrm{O}$ and $\mathrm{BaO}$ than that in 14310,6 (fig. 3 ).

(5) The Ni content of the metal phase in 14053,17 is distinctly lower than that in 14310,6.

(6) Thin section 14310,6 contains more $U$ and $T h$ than thin section 14053,17 (as indicated by fission track studies), and contains both the unknown U-Thrich phase and the unknown red Fe-Ti-Zr silicate, neither of which are found in thin section 14053 .

Based on these criteria, samples $14001,7,3$, and 14073,8 , despite the presence of abundant orthopyroxene, can be correlated with 14310 on petrologic grounds in agreement with all the isotopic data. Similar glass composition and the restricted pyroxene compositions, suggest that sample $14167,8,1$ can also be correlated with 14310 in agreement with the age assignment, but not the cosmic ray exposure age. However, the high olivine content and lack of other supporting evidence makes this correlation much less certain.

On the basis of its texture, its high plagioclase content, its lack of apparent Fe enrichment in the pyroxene, the high $\mathrm{Ni}$ content of its metal, and the glass composition, sample $14321,191, \mathrm{X}-1$ is more like 14310 than 14053 , although it lacks the red Fe-Ti-Zr silicate. This correlation is neither in agreement with the age assignment nor the cosmic ray exposure age.

The distribution of lithologic types in the dated Apollo 14 samples, as well as cursory examination of thin sections of breccia samples 14321,$218 ; 14305,13$; 14083,7 and 8 , and 14311 suggest that rock fragments that may be correlative with sample 14310 on the basis of mineralogic and petrologic similarities are important constituents of the soil and breccia at the Apollo 14 site. This is corroborated by the bulk chemical analysis [1] as both the major and minor element patterns of rock 14310 recur as the dominant pattern in the breccia and soil, and is distinctly different from the elemental abundances reported in sample 14053. Moreover, the Preliminary Examination Team reports that the three most abundant (nonfragmental) lithic clasts in the fragmental rocks are (1) clinopy roxene-plagioclase clasts with basaltic texture, (2) feldspathic clasts, and (3) plagioclase-orthopyroxene clasts with ophitic textures and minor clinopyroxene [1]. The first two types could be derived from rocks like either sample 14310 or 14053 , but the third type is distinctive and similar to 14073. 
Hence, it seems likely that most of the fragmental rocks at the Apollo 14 site will be composed of rocks with ages similar to these few dated samples. It might be noted that all lithic fragments at both the Apollo 11 and 12 sites, with the exception of rock 12013 had a limited age span suggesting local or closely related origin of the rocks.

Orthopyroxene grains in the soil, orthopyroxene basalt fragments with distinctive petrologic, chemical, and mineralogic features, and glass (fragments) with similar chemical composition have now been reported from the Apollo 11 samples [6,15], from the Apollo 12 samples $[14,16,17,23]$, and the Apollo 14 samples ([1], this paper). Sources for this material, therefore, must be widely available on the lunar surface. It has been suggested that such material is the 'magic', 'cryptic' or 'KREEP' component invoked to explain the chemical and isotopic differences observed between the Apollo 11 and 12 soils and the dominant rock fragments which they contain [17].

Sample 14073 is an or thopyroxene basalt, and judging by its mineral content, is rich in K, REE, U and Th. Thus, it exhibits chemical similarities to the 'magic' and 'cryptic' components and 'KREEP'. It has an age of $3.88 \mathrm{AE}$ and an initial ${ }^{87} \mathrm{Sr} /{ }^{86} \mathrm{Sr}$ of 0.70034 . Rocks like rock 14073 may be the source of orthopyroxene crystals, or thopyroxene fragments, $\mathrm{K}_{2} \mathrm{O}$-rich glass and REE which occur as components in the soil.

As described earlier, Luny Rock 1 from Apollo 11 [6] and 14001,7,1 are notably similar in both their pre-shock and their shock features. They have model ages, $T_{\mathrm{BABI}}$, of 4.44 and $4.30 \mathrm{AE}$ respectively [2,24]. Assuming for argument's sake that they are cogenetic, the resulting two point isochron has an age of $3.95 \mathrm{AE}$ and an initial ${ }^{87} \mathrm{Sr} /{ }^{86} \mathrm{Sr}$ of 0.70068 . Data for a similar orthopyroxene basalt fragment [17] also fall, well within its error bars, on this isochron.

Comparing these points it seems important to recognize that the 'magic' or 'cryptic' component, which was invoked to account for the chemical and isotopic differences of the lunar soils from their dominant rock fragments, need not be granitic rock like 12013, but may be a lithic type like 14073 or its shocked counterparts (?) like 14001,7,1 and Luny Rock 1.

\section{Acknowledgements}

We gratefully acknowledge G.J.Wasserburg for his care and foresight in selecting fragments from the soil and breccia samples. Continuing discussions with G.J. Wasserburg and other Lunatics have proved invaluable. E.L.Haines provided the fission track data and Mr.

Joe Brown meticulously prepared the micro-thin sections.

This work was supported by NASA contract NAS9-8074. The microprobe laboratory has been developed with the support of NSF, JPL and the Union Pacific Foundation.

\section{References}

[1] Lunar Sample Preliminary Examination Team, Preliminary examination of lunar samples, in: NASA Manned Spacecraft Center, Apollo 14 Preliminary Science Report SP-272 (1971) 109.

[2] D.A.Papanastassiou and G.J.Wasserburg, Rb-Sr ages of igneous rocks from the Apollo 14 mission and the age of the Fra Mauro Formation, Earth Planet. Sci. Letters 12 (1971) $36-48$.

[3] G.Turner, J.C.Huneke, F.A.Podosek and G.J.Wasserburg, ${ }^{40} \mathrm{Ar}-{ }^{39} \mathrm{Ar}$ ages and cosmic ray exposure ages of Apollo 14 samples, Earth Planet. Sci. Letters 12 (1971) 19-35.

[4] A.E.Bence and A.L.Albee, Empirical correction factors for the electron microanalysis of silicates and oxides, J. Geol. 76 (1968) 382.

[5] A.L.Albee and L.Ray, Correction factors for electron probe micro-analy sis of silicates, oxides, carbonates, phosphates and sulfates, Analy tical Chem. 42 (1970) 1408 .

[6] A.L.Albee and A.A.Chodos, Microprobe investigations on Apollo 11 samples, Geochim. Cosmochim. Acta, Suppl. I, vol. 1 (1970) 135.

[7] L.H.Fuchs, Fluorapatite and other accessory minerals in Apollo 11 rocks, Geochim. Cosmochim. Acta, Suppl. I, vol. 1 (1970) 475.

[8] NASA Manned Spacecraft Center, Apollo 14 Preliminary Science Report, SP-272 (1971).

[9] G.J.Wasserburg, private communication.

[10] N.L.Carter, I.S.Leung, H.G.Ave'Lallemant and L.Fernandez, Growth and deformational structures in silicates from Mare Tranquillitatis, Geochim. Cosmochim. Acta, Suppl. I, vol. 1 (1970) 267.

[11] S.E.Haggerty and H.O.A.Meyer, Apollo 12: opaque oxides, Earth Planet. Sci. Letters 9 (1970) 379. 
[12] E.Roedder and P.W.Weiblen, Lunar petrology of silicate melt inclusions, Apollo 11 rocks, Geochim. Cosmochim. Acta, Suppl. I, vol. 1 (1970) 801.

[13] N.M.Short, The nature of the moon's surface: evidence from shock metamorphism in Apollo 11 and 12 samples, Icarus 13 (1970) 383.

[14] L.H.Fuchs, Or thopyroxene-plagioclase fragments in the lunar soil from Apollo 12, Science 169 (1970) 866.

[15] J.A.Wood, U.B.Marvin, B.N.Powell and J.S.Dickey Jr., written communication.

[16] J.A.Wood, U.B.Marvin, J.B.Reid Jr., G.J.Taylor, J.F. Brown, B.N.Powell and J.S.Dickey Jr., written communication.

[17] N.J.Hubbard, C.Meyer Jr., P.W.Gast and H.Weismann, The composition and derivation of Apollo 12 soils, Earth Planet. Sci. Letters 10 (1971) 341.

[18] Lunatic Asylum, Mineralogic and isotopic investigations on lunar rock 12013, Earth Planet. Sci. Letters 9 (1970) 137.

[19] E.L.Haines, A.L.Albee, A.A.Chodos and G.J.Wasserburg, Uranium-bearing minerals of lunar rock 12013, Earth Planet. Sci. Letters, to be published.
[20] N.J.Page, L.C.Calk and M.H.Carr, Problems of small particle analy sis with the electron microprobe, U.S. Geol. Survey Prof. Paper 600-C (1968) C31.

[21] E.L.Haines, private communication.

[22] C.Fick, T.C.Highes, J.F.Lovering, A.F.Reid, N.G.Ware and D.A.Wark, Electron probe, fission track and activation analysis of lunar samples, Second Lunar Science Conference, Houston, Texas, January (1971).

[23] K.Keil, M.Prinz and T.E.Bunch, Mineralogical and petrological aspects of Apollo 12 rocks, Second Lunar Science Conference, January (1971).

[24] A.L.Albee, D.S.Burnett, A.A.Chodos, O.J.Eugster, J.C. Huneke, D.A.Papanastassiou, F.A.Podosek, G.Price Russ III, G.Sanz, F.Tera and G.J.Wasserburg, Ages, irradiation history, and chemical composition of lunar rocks from the Sea of Tranquility, Science 167 (1970) 463. 